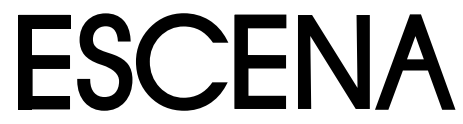

Revista de las artes
Publicación semestral. ISSN 2215-4906

Volumen 78 - Número 2

Enero - Junio 2019

\title{
Potencias y alianzas de supervivencia entre mujeres. Liliana Maresca, un recorrido por su obra
}

\author{
Powers and Alliances of Survival among Women. \\ Liliana Maresca, a reading of her Work
}

Alicia Vaggione

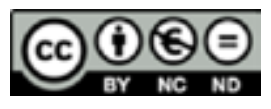

Esta obra está bajo una licencia Creative Commons Reconocimiento-No comercial-Sin Obra Derivada 


\title{
Potencias y alianzas de supervivencia entre mujeres. Liliana Maresca, un recorrido por su obra
}

\author{
Powers and Alliances of Survival among Women. \\ Liliana Maresca, a Reading of her Work
}

\author{
Alicia Vaggione ${ }^{1}$ \\ Universidad Nacional de Córdoba \\ Argentina
}

Recibido: 5 de febrero del 2018 Aprobado: 7 de mayo del 2018

\begin{abstract}
Resumen
En las narrativas sobre sida la voz que prima no es la de las mujeres. Aquí me interesa considerar esas voces y leerlas en los ecos de sus fuerzas. Este ensayo, centrado en la figura de la artista Liliana Maresca (1951-1994) atiende a la singularidad de su propuesta estético/política leída en conexión con la de otras mujeres (Marta Dillon y Gabriela Liffschitz, 1963-2004), en el punto en que gestionan modos de experimentar el cuerpo y la enfermedad activando nuevas formas de supervivencia.
\end{abstract}

Palabras clave: enfermedad; mujeres; experiencia; intervenciones estético/políticas; supervivencia

\begin{abstract}
In narratives about AIDS, the important voice is not women's. Here I am interested in reading those voices in the echoes of their forces. This writing focuses on the aesthetic proposal of the artist Liliana Maresca (1951-1994) and read it in relation to those other women (the writer, Marta Dillon and the protographer, Gabriela Liffschitz -1963-2003-). In this essay, I am interested in analyzing how they construct ways of experiencing the body and disease and how they activate new forms of survival.
\end{abstract}

Keywords: illness, women, experience, aesthetic political interventions, survival

\footnotetext{
1 Profesora Adjunta por Concurso en el Área de Semiótica del Centro de Estudios Avanzados, de la Facultad de Ciencias Sociales, Universidad Nacional de Córdoba, Argentina. Doctora en Semiótica por la misma institución. Correo electrónico: aliciavaggione@gmail.com
} 


\section{Introducción}

En las narrativas sobre sida la voz que prevalece no es la de las mujeres. Lina Meruane en Viajes Virales. La crisis del contagio global en la escritura del sida, lo señala: "las mujeres explicitan, de inicio, un estatuto negativo en la seropositividad: al cuerpo de la mujer se le hurta su posible carga viral, retrasando su ingreso, el de su voz, el de su experiencia, al relato de la epidemia" (2012, p. 229). Aquí me interesa considerar esas voces que no ocuparon la centralidad de la escena y leerlas en las potencias que activan para pensar la experiencia de la enfermedad. Este ensayo se ocupa principalmente de la figura de la artista Liliana Maresca (1951-1994) y tiene como propósito, a partir de un recorrido fragmentario por su obra, entrever las apuestas que, centradas en torno al cuerpo, se activan para responder a una serie de problemáticas que se corresponden con un tiempo/espacio particular.

Me interesa atender a la singularidad de la propuesta estético-políica de Maresca, pero también ponerla en relación con la experiencia de otras mujeres que construyen su propio relato de la enfermedad. Esto es, leerla en el espacio común que se genera al poner en primer plano, no solo la condición vulnerable de los cuerpos sino también, sus posibilidades de supervivencia. Dicho en otros términos, me interesa considerar los sentidos que se activan desde la mirada femenina, cuando esta recibe los embates del mundo, ya sea para actualizar sus deseos o, cuando desafiante, se ve obligada a inventar nuevas maneras para enfrentar la condición precaria de la vida. De este modo, me detengo -muy brevementeen las apuestas estético-políticas de la escritora y periodista, Marta Dillon y de la fotógrafa, Gabriela Liffschitz². Considero que las intervenciones realizadas por cada una, apreciadas en su exquisita singularidad, pueden también ser articuladas en una mirada transversal atenta a indagar sus resonancias, sus juegos de re-envíos, su capacidad para actualizar una reinvención constante de sí -abierta a los otros- en cualquier circunstancia.

\section{Liliana Maresca en la mirada de Dillon}

Me interesa aquí, detenerme principalmente en la mirada de Dillon sobre Maresca, como artista que admira, como mujer que activa sus deseos y le da la posibilidad de volverse sobre sí y entrever un camino para continuar ${ }^{3}$. En el marco de las escrituras sobre sida en

2 Cabe aclarar que en el caso de Liffschitz la enfermedad que se aborda no es el VIH/Sida, sino el cáncer de mama. No obstante, las apuestas que la artista lleva adelante para desbaratar los imaginarios hegemónicos del cuerpo enfermo, la ubican en una línea próxima a la de las intervenciones estéticas aquí reunidas.

3 Además de escritora y periodista, Dillon es una de las referentes del colectivo Ni una menos que surge, en el año 2015 en Argentina, como una forma de visibilizar y luchar contra las violencias y 
Potencias y alianzas de supervivencia entre mujeres.

Artículos

Liliana Maresca, un recorrido por su obra

Argentina, Dillon ocupa un lugar central. Es una de las primeras mujeres que, como señala Lina Meruane, a partir de la experiencia de la enfermedad: "ejemplifica el modo en que lo personal revierte en una posición radicalmente política” (2012, p. 84). Las columnas que, desde 1995 escribe en el "Suplemento No" del diario Página 12, luego reunidas en el libro Vivir con virus. Relatos de la vida cotidiana (2004), dan cuenta de una escritura que contempla un abanico de problemas en torno a la dolencia ${ }^{4}$. Una escritura que permite observar el pasaje de la enfermedad de su condición mortal a crónica. Dillon insistirá en relatar la fuerza estigmatizante de la enfermedad, la discriminación laboral -sobre todo en los primeros tiempos-, la dificultad de contar que se es portador, las redes solidarias que se activan entre los afectados, las complicaciones burocráticas para acceder a los tratamientos y la peligrosidad de su detención cuando los medicamentos faltan o escasean. Hay también, en la escritura de las crónicas, una indagación permanente del cuerpo y sus estados, relatos ligados a las rutinas de la toma cotidiana de la medicación, los efectos colaterales que producen, los modos de control disciplinario que los tratamientos imponen y una vacilación permanente en torno a los límites entre lo seguro, lo recomendable y lo saludable. Todas estas cuestiones, al unísono, crean líneas de sentidos tendientes a construir una mirada reflexiva sobre la enfermedad y generan un margen de resistencia en el que lo vital es el horizonte que orienta la deriva.

Casi diez años después de la publicación de Vivir con virus... en formato libro, Dillon escribe Aparecida (2015), narración en la que relata el hallazgo de los restos óseos de su madre, víctima de la última dictadura militar argentina. En este texto cruzado por intensidades y relatos amorosos, la conmoción ante el encuentro de los restos impulsa una escritura en la que la figura de la madre ansiosamente buscada será recompuesta desde el presente. Dillon volverá a entablar un vínculo con la madre ausente mientras nos relata los afectos que la sostienen en su día a día. Su relación de pareja con Albertina Carri, cineasta, el niño que entre ambas tienen, más la presencia de Naná, la hija mayor, conforman un círculo afectivo que, como las ondas que se dibujan cuando cae una piedra al agua, no dejará de expandirse. Aparecida que recibió desde su publicación una cantidad importante de lecturas críticas en el ámbito académico, despliega el entramado de una extensa red de afectos. En ese entramado, en el que la madre que se es, se refracta en la que se ha tenido y en la

crímenes ejercidos contra las mujeres. Las principales consignas del movimiento son rápidamente consideradas por las feministas de otros lugares del mundo.

4 En Literatura/enfermedad. Escrituras sobre sida en América Latina trabajé Vivir con virus ... en un último apartado titulado "Hacia otro por-venir" (2012, pp. 209-221).

ESCENA. Revista de las artes, 2019, Vol. 78, Núm. 2 (enero-junio), pp. 56-70 
conmoción que produce la reaparición de sus restos, hay un relato construido en torno a Maresca. Maresca muere a causa de las complicaciones producidas por el $\mathrm{VIH} / \mathrm{sida}$, dos años antes que aparezcan los tratamientos farmacológicos efectivos y en su obra se deja leer la potencia de un cuerpo que se activa y revela ante una serie de problemáticas diversas.

El relato de Dillon se detiene precisamente en ese final de trayecto vital de la artista componiendo una escena en la que eros y tánatos se superponen: "la primera vez que me enamoré de una mujer fue durante su agonía"5 (2015, p. 159). Dillon nos relata, los días finales de su amiga, en los que a pesar del quiebre que produce la proximidad de la muerte, algunos gestos mínimos de lo cotidiano permanecen presentes: "disfrutando de la rica comida, mitigando el dolor tanto como fuera posible, dibujando y escribiendo en los paspartús que nos ocupábamos que tuviera a mano" (2015, p. 160).

De esa escritura de la artista, Dillon transcribe unos versos: "que la pequeña luz deje de brillar no cambia nada/Todo va a seguir igual/El alimento se desvanecerá/Alguna lágrima resbalará/En el surco de alguna mejilla/Y cada uno se dedicará por si acaso/A vivir más su propia vida" (2015, p. 160). La lucidez del poema, no solo concibe la propia vida en el momento de su cese sino que imagina la de los otros en el despliegue de su afirmación. Para Dillon la cercanía con ese tiempo final, la imposibilidad inmediata de comprender lo enunciado en el poema: "toda mi vida se transformaba bajo su resplandor, ¿cómo podía decir que no cambiaba nada?" (2015, p. 160), se convierte en una fuerza que potencia la supervivencia. Y hay más, unas palabras finales que le están directamente dirigidas:

La observaba alejarse lentamente de la vida ... no me estaba enseñando a morir sino que me impulsaba a vivir con una garra que yo intuía pero no sabía que tenía. -El cuerpo ya lo puse yo, Dillon, ya está -me decía ... [el destacado no pertenece al original] $(2015$, p. 160).

Veamos entonces las apuestas de ese cuerpo, veamos el cuerpo de Maresca tal como nos deja vislumbrarlo su obra.

5 Francisco Lemus, historiador de arte, en "Liliana Maresca: fotoperformance, registros y homenajes" señala dos puntos cruciales en la vida de la artista que se asemejan, se cruzan, se parecen a los de Dillon: "Dos momentos extremos se presentan en la trayectoria de Liliana Maresca. El primero fue la huida de la vida conyugal burguesa, el segundo fue su diagnóstico positivo de VIH en 1987; en adelante, su producción adquirió mayor intensidad, todo pareció infectarse" (2017, p. 1). 
Potencias y alianzas de supervivencia entre mujeres.

Artículos

Liliana Maresca, un recorrido por su obra

\section{Tramas de cuerpos y conflictos}

Francisco Lemus señala una característica singular de la producción de Maresca: su interés por formar parte de comunidades artísticas en un movimiento donde lo autoral pierde fuerza y se deja de lado a favor de inscripciones "estéticas plurales y efímeras" (2017, p. 1). Mario Cámara, en su ensayo De aquel amor de música ligera. Liliana Maresca y la escena de los '80 en Buenos Aires ${ }^{6}$ (2015) también inscribe la producción de la artista en un espacio colectivo regido por la presencia de ciertas marcas: la centralidad del cuerpo y la precariedad.

Los artistas cuyas manifestaciones pueden ser pensadas juntas, y que el crítico reúne, son Jorge Gumier Maier, Marcos López, Néstor Perlongher, Alejandro Kuropatwa, El club del clown, Las gambas al ajillo, Las inalámbricas, Los Twits, Patricio Rey y Los redonditos de Ricota, Virus, Marcia Schvartz y Liliana Maresca. Es una una lista que no tiene pretensiones de exhaustividad y que remite a varios lenguajes estéticos de inscripción (pintura, fotografía, performance, música, entre otros) y a lugares específicos de manifestación y exposición en la ciudad de Buenos Aires. Ante un tiempo atravesado por amenazas polivalentes -muchas de las intervenciones artísticas ocurren en los años finales de la dictadura- una de las resistencias que el colectivo apunta y/o efectúa es posicionarse en términos de lo que uno de sus participantes, Roberto Jacoby denominó "estrategias de la alegría"7 . Esto es, la actualización de una consigna vital que ante un cuerpo sufriente, atravesado por las prácticas disciplinarias y ominosas de la dictadura, se revelara en una contraposición que diera lugar a "un cuerpo danzante, insubordinado, travestido" (Cámara, 2015, p. 3).

En la escena cultural de la década de 1980 y en su desplazamiento hacia los comienzos de la década de 1990, uno podría pensar en términos de co-existencias, solapamientos, pluralidades y superposiciones que dibujan una trama compleja de intervenciones estético/ políticas en la que aparecen tantas figurativizaciones de cuerpos como conflictos y en la que

${ }^{6}$ La noción de escena que Cámara trabaja, remite a los planteamientos de Nelly Richard -que la utiliza para pensar los grupos artísticos que participaron en Chile en el mismo período- y resulta operativa en tanto le permite construir un objeto y remarcar su grado de dispersión. En términos de Cámara "la escena agrupa sin cohesionar, resguarda el carácter inorgánico y heterogéneo del movimiento" (2015, p. 3).

7 Un cuerpo que apelara como estrategia de resistencia a ciertas formas de la liviandad y del placer, algo que el grupo de música de rock Virus -con la figura estelar de Federico Moura- se encargó de inscribir y desplegar en la escena cultural del momento y cuyas resonancias, producto de la popularidad de la música, llegan hasta nuestros días.

ESCENA. Revista de las artes, 2019, Vol. 78, Núm. 2 (enero-junio), pp. 56-70 
podemos ubicar las intervenciones de Maresca. Con un último rasgo que me interesa destacar, señalado por Lemus: "Maresca no es una artista de la identidad, sino de la afinidad con otros, con dispositivos y experiencias que la hacían salirse de sí misma" (2017, p. 1).

\section{Una mirada fragmentaria de la obra de Liliana Maresca}

Como venimos señalando, la producción artística de Maresca durante la década de 1980 y primeros años de la década de 1990, se deja leer en el cruce de una serie de acontecimientos que la atraviesan y conmueven. Los años finales de la dictadura y los primeros de la democracia en Argentina, la irrupción del $\mathrm{VIH} /$ sida a escala global -alcanzando un estado epidémico en los países del primer mundo y dispersándose rápidamente por los contornos del globo- la agudización de la implementación de la lógica neoliberal que tendrá su corolario en la década de 1990.

Indagar su obra supone considerar las múltiples problemáticas que convoca, así como vislumbrar formas de indagación y resistencia que se centran en un cuerpo que no adquiere una forma fija, sino que se reactiva cada vez dialogando con instancias singulares. No habría una unidad o principio estético identificable cuyo desarrollo como espectadores podríamos observar, más bien lo que recibimos son apuestas, intervenciones singulares en las que incluso la enfermedad no aparece de forma evidente. Lo que aquí presento son deslizamientos, recorridos, miradas fragmentarias sobre su obra con la atención puesta en la figurativización del cuerpo. De la década de 1980 selecciono, Liliana Maresca con su obra $(1983)^{8}$ y Cristo autotransfundiéndose (1988). En el pasaje hacia la década de 1990, me detengo en Imagen pública/Altas esferas (1993) ${ }^{9}$. Liliana Maresca con su obra se corresponde con una serie de fotografías en blanco y negro, en las que la artista presenta su cuerpo desnudo en conexión con una serie de objetos creados por ella -resultantes del ensamble de piezas- (ver imágenes 2. 1 a 5). Las imágenes son tomadas por el fotógrafo Marcos López y componen una multiplicidad de sentidos en torno al cuerpo.

La serie constituida por cinco imágenes comienza con una, en la que el cuerpo de la artista, retratada de pie, es atravesado por el objeto que sostiene. Una pieza de metal se asemeja al torso femenino con sus senos y desde él salen unos caños corrugados que parecen alcanzar las formas de un material orgánico. Los caños como tráqueas o como arterias se incrustan en el cuello, en el brazo. Las manos cubren el sexo.

8 Liliana Maresca. Sin título. Liliana Maresca con su obra. Fotografía Marcos López. Año 1983. Fotoperformance.

9 Liliana Maresca. Sin título. Imagen pública - Altas esferas. Fotografía Marcos López. Año 1993. Fotoperformance. 
Potencias y alianzas de supervivencia entre mujeres.

Liliana Maresca, un recorrido por su obra

Imagen 1. Sin título, serie Liliana Maresca con su obra, 1983

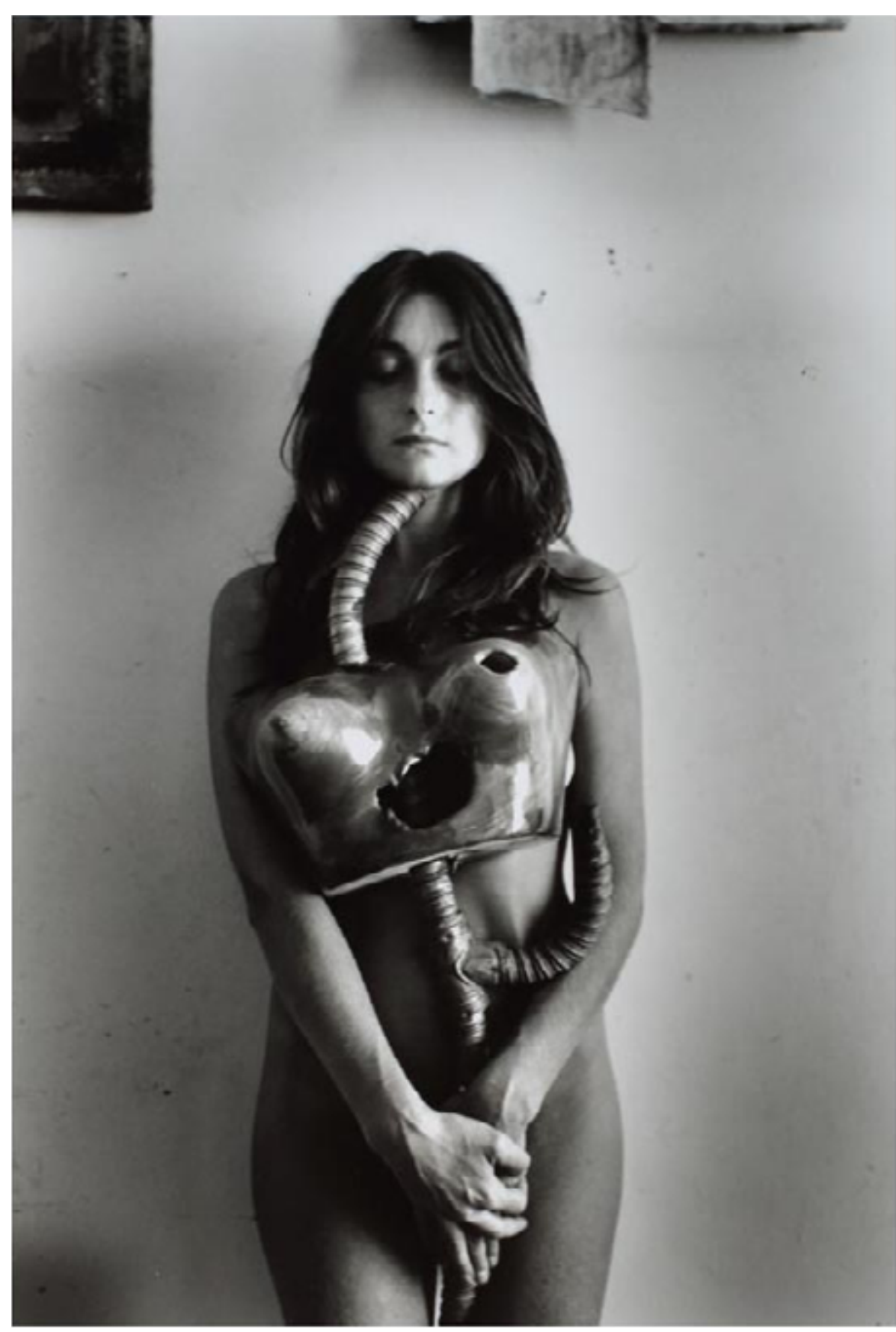

Fuente: Fotografía de Marcos López (1983). Archivo Liliana Maresca.

ESCENA. Revista de las artes, 2019, Vol. 78, Núm. 2 (enero-junio), pp. 56-70 
En la segunda imagen, la pieza está flotante, los brazos la levantan para que cubra el cuerpo. Las superficies se entremezclan, un metal más liviano da lugar a la turgencia excesiva de los senos en contraste con otra pieza de metal duro y pesado, ambas engrampadas a una pieza de madera tallada. Por debajo la piel desnuda, un rostro que se recorta en la mirada y el vello púbico que asoma abundante y oscuro introduce otra textura a esta yuxtaposición de materias.

\section{Imagen 3. Sin título, serie Liliana Maresca con su obra, 1983}

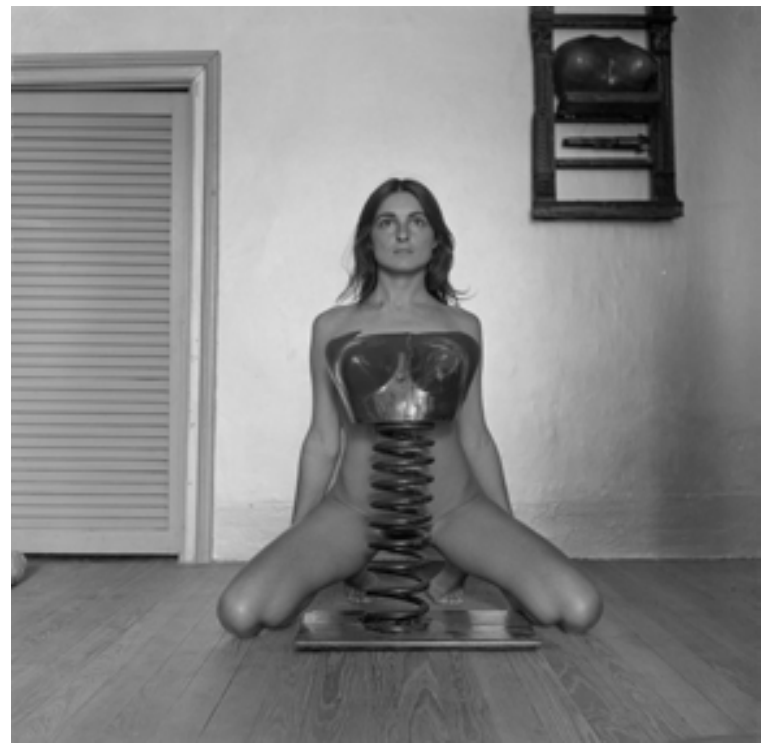

Fuente: Fotografía de Marcos López (1983). Archivo Liliana Maresca.

\section{Imagen 2. Sin título, serie Liliana Maresca con su obra, 1983}

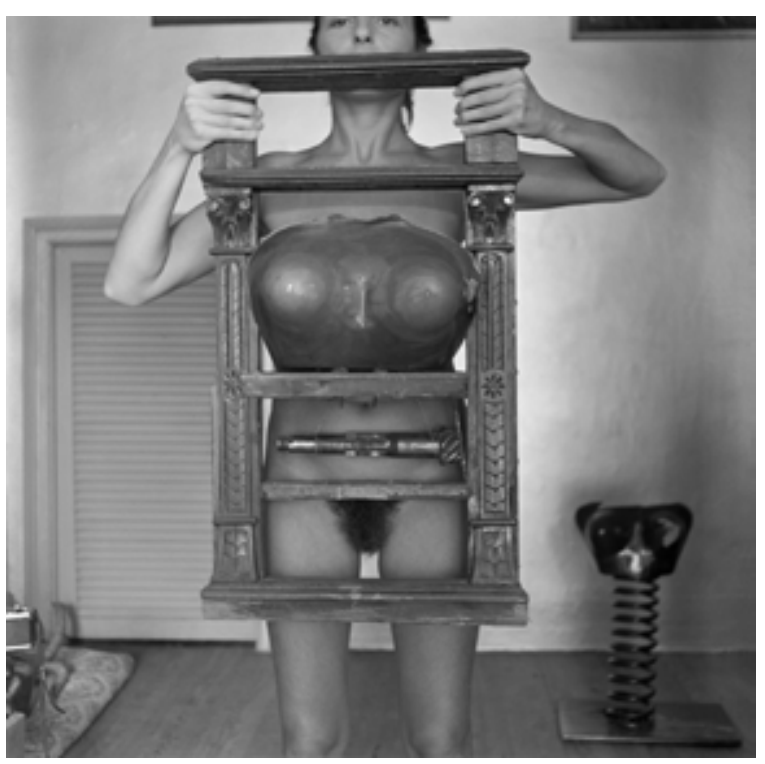

Fuente: Fotografía de Marcos López (1983). Archivo Liliana Maresca.
La tercera vuelve a centrarse sobre el cuerpo desnudo, aquí el rostro aparece despejado, la mirada dirigida hacia arriba. El cuerpo está detrás de la pieza ensamblada, ajustándose a ella. La pieza lo cubre, otra vez unos senos gigantes de metal y un resorte inmenso -pieza de desecho de alguna máquina- que como un centro de gravedad retiene al cuerpo, lo fija. La imagen acentúa el contraste entre un rostro cuya mirada se eleva y una materialidad pesada, la de la pieza, que fija el cuerpo a un centro, un eje. 


\section{Imagen 4. Sin título, serie Liliana Maresca con su obra, 1983}

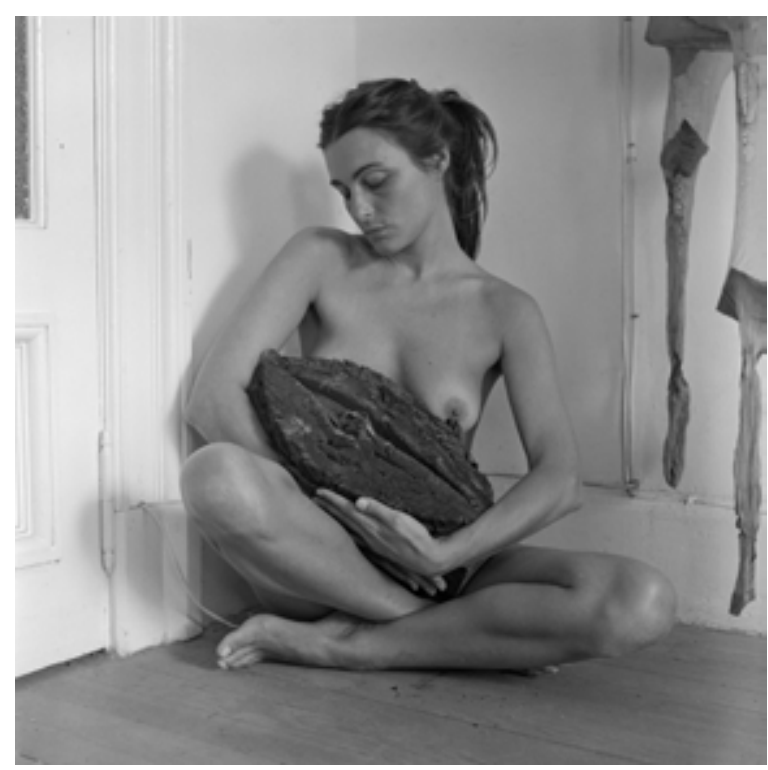

Fuente: Fotografía de Marcos López (1983). Archivo Liliana Maresca.
En la cuarta, la artista sostiene entre sus brazos, una pieza compacta de materia orgánica. La atención del espectador se centra en la imagen del cuerpo desnudo, su posición en cuclillas, la disposición envolvente de los brazos y un rostro, cuya mirada ensoñada se dirige maternalmente al objeto que posee. Fuera de esta imagen envolvente centrada sobre un cuerpo cuya superficie es cálida y vital, cuelgan unas medias de nylon de mujer, rotas y deshilachadas, que introducen un desajuste, una disonancia en la composición general de la fotografía.
Finalmente, la serie termina con la artista sentada en una reposera, el cuerpo desnudo y relajado, la mirada distante. Sobre la pared, vemos colgada una pieza inmensa con protuberancias que parecen senos unida a una pieza de metal en el centro y formas circulares en las que a modo de manchas aparecen contrastes entre colores.

\section{Imagen 5. Sin título, serie Liliana Maresca con su obra, 1983}

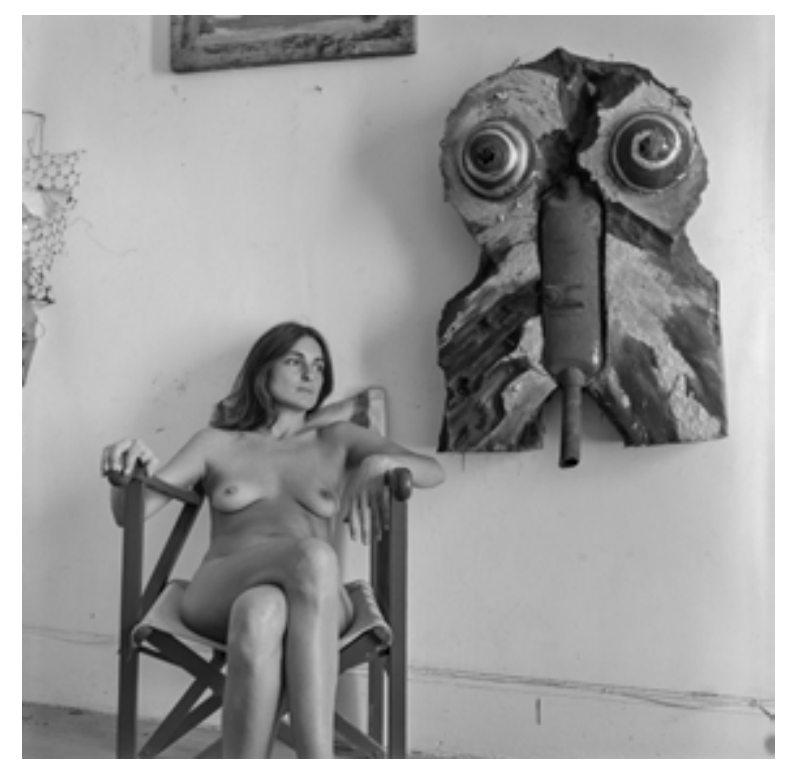

Fuente: Fotografía de Marcos López (1983). Archivo Liliana Maresca. 
En conjunto, las imágenes de la serie producen múltiples combinaciones entre las piezas u objetos creadas por la artista y su cuerpo desnudo fotografiado. Una ambivalencia singular entre la obra que se introduce en el cuerpo -a veces simplemente se sostiene, otras, se inserta o se incrusta- y el cuerpo que deviene obra. Los efectos de sentido giran inquietantes, solapados, yuxtapuestos. En la belleza del cuerpo desnudo, en la piel que se exhibe se inscribe algo del orden de lo suave y mucho del cuerpo herido, las piezas duras que se aproximan al cuerpo no terminan de ajustarse a sus contornos y activan resonancias o ecos de cuerpos violentados, torturados. Además de desorganizar los límites del cuerpo, desdibujando las fronteras de lo corporal en el ajuste y/o desajuste con las piezas que lo atraviesan.

La segunda obra sobre la que me interesa detenerme es la que lleva por nombre Cristo autotransfundiéndose (1988) - de ella solo se conserva una foto sacada durante la exposición ${ }^{10}$-. Muestra a un Cristo crucificado, en el extremo de la peana donde se fija la figura hay un recipiente donde se acumula la sangre que -a partir de un dispositivo insertocircula por las heridas de ese cuerpo en un movimiento incesante. Si la transfusión es esa técnica en la que la sangre se transfiere de un cuerpo a otro para posibilitar la vida, ¿está jugando la imagen, en la actualización de la autotransfusión, con un Cristo que se sobrevive a sí mismo? ¿O simplemente la circulación sanguínea acentúa su condición sufriente? Cualquiera sean los sentidos que active, la imagen del Cristo autotransfundiéndose pone en el centro de la atención el valor de la sangre como un bien que el sida viene a potenciar. La sangre y sus simbolismos atávicos adquirían importancia y desplegaban nuevas significaciones con la llegada de la enfermedad ${ }^{11}$.

La obra de Maresca, expuesta en el Centro Cultural de Buenos Aires, hoy Centro Cultural Recoleta, no se mostró sola, sino que formó parte de las actividades organizadas por un colectivo de mujeres denominado Mitominas ${ }^{12}$ que tenía como propósito, a partir de

${ }^{10}$ Para su visualización, remitimos a http://www.cvaa.com.ar/02dossiers/maresca/imagenes/ obra/03_grande/1988_mar_11a_gr.jpg

${ }^{11}$ Como lo advertía Néstor Perlonguer en el ensayo El fantasma del sida, escrito desde la urgencia y con el objeto de desactivar los sentidos apocalípticos que la dolencia producía en el momento de su irrupción: "una enfermedad relacionada con lo sexual toca un punto particularmente sensible para la sociedad contemporánea, tan preocupada con la higiene y el cuidado del cuerpo. A este pesado estigma, signo de múltiples reglas de orden social, se agrega, en el caso particular del SIDA, otra complicación derivada de la posibilidad de que la enfermedad sea transmitida por la sangre" (1987, p.12).

12 "El proyecto Mitominas se concretará en tres exposiciones - dos en la década de 1980 y una en la de 1990- las que tienen por objeto cuestionar y proponer otras miradas sobre los mitos 
Potencias y alianzas de supervivencia entre mujeres.

un encuentro abierto e interdisciplinario en el que se reunían activistas, cineastas, escritoras, artistas plásticas, entre otras; develar y sobre todo deconstruir y corroer el lugar asignado a las mujeres en los mitos. El Mitominas II, desarrollado en el año 1988 se centró en el análisis de los mitos de la sangre. La agenda política del evento cruzó discusiones y reflexiones en torno a la violencia de género con las de la problemática que la irrupción del sida traía a escena, en lo que puede ser leído desde el presente como un gesto anticipatorio dado que en esos años los relatos de la enfermedad estaban nucleados fuertemente en torno a la comunidad homosexual masculina.

Imagen 6. Sin título, serie Imagen pública-Altas esferas, 1993

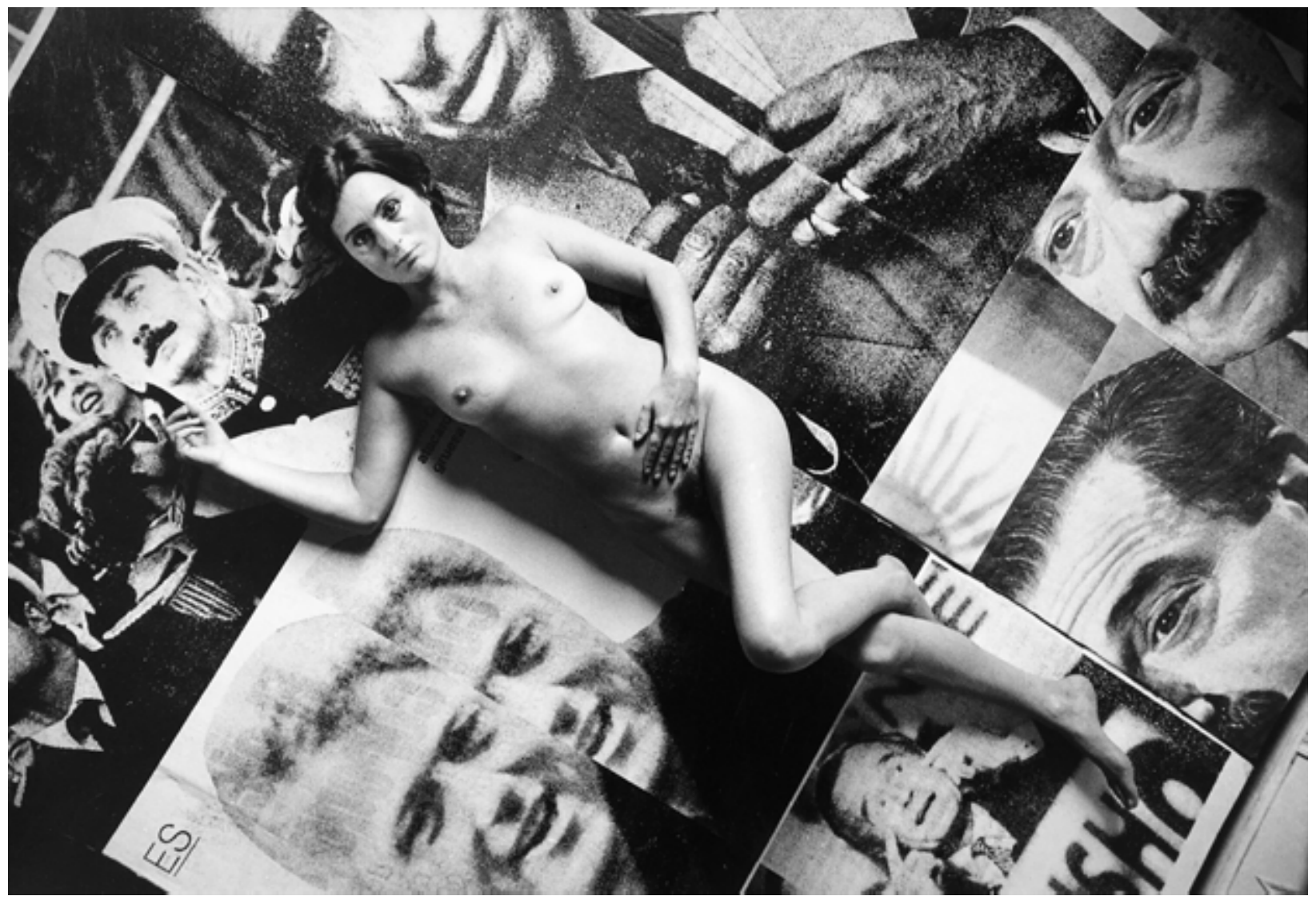

Fuente: Archivo Liliana Maresca.

grecolatinos y precolombinos. La propuesta pondrá el acento sobre el poder que los mitos han tenido para definir las características de 'lo femenino'” (Rosa, 2011, p. 190). 
La obra de Maresca despertó la inquietud de los curas de una iglesia próxima a la exposición y se solicitó su retiro. Según se lee, en diferentes relatos de mujeres que organizaron el encuentro citadas por María Laura Rosa (2011, pp. 343-347), la obra no fue retirada sino cambiada de lugar y expuesta en un sitio más periférico de la muestra. Ya en tránsito hacia la década de 1990, en Imagen pública/Altas esferas (1993) -Ver Imagen 10.2- Maresca construye un inmenso collage -con fotos extraídas de un periódico local- de los personajes políticos de Argentina que traen los tiempos de la dictadura, Jorge Rafael Videla, del retorno de la democracia, Raúl Alfonsín y de la agudización de la presencia del neoliberalismo, Carlos Saúl Menem. También convoca las imágenes de Bill Clinton y de George Bush. Sobre estas fotos que construyen una escena de tiempos políticos transcurridos y superpuestos, Marcos López la vuelve a fotografiar con su cuerpo desnudo recostado sobre ellas. La desnudez centelleante de su cuerpo, una pierna cruzada que cubre su entrepierna, un brazo extendido que se posa sobre la foto del dictador, contrasta con las imágenes duras en blanco y negro de las figuras convocadas. Su mano posada sobre la suavidad del vientre se opone a las que se cruzan grandes y toscas en la foto de Menem. Lemus lee aquí, una simultaneidad en la que "todo parecería estar en el mismo intercambio de fluidos -los signos del neoliberalismo y un virus transnacional como el sida" (2017, p. 1). No hay marcas del desgarro de la enfermedad, hay un cuerpo infectado y deseante.

Nos parece que Imagen pública/Altas esferas puede ser leída hoy como una postal de época. Icónica en las figuras que convoca y desafiante en cuanto a los cuerpos que pone juntos. Cuerpos que representan las políticas que activó el neoliberalismo dejando por fuera de vidas dignas de ser vividas a una innumerable cantidad de sujetos, las políticas que en los Estados Unidos se ejercieron con la irrupción de la enfermedad demorando el financiamiento y posibilitando que la epidemia alcanzara niveles de mortandad inmensos. Sobre el tapiz que forman las figuras del collage, el cuerpo de Maresca brilla y su mirada nos interpela ${ }^{13}$. Decíamos antes que no encontramos una unidad de estilo -por decirlo de algún modo- en la estética que Maresca nos propone, si siguiéramos abriendo el archivo de los materiales que realizó nos seguiríamos encontrando con apuestas específicas y distintivas. No obstante, hay una recurrencia en la presencia de su cuerpo desnudo siempre abierto, como sostiene Lemus, a experiencias que la hacen salir fuera de sí.

13 Al finalizar la muestra, las imágenes son llevadas a la Reserva Ecológica de la ciudad de Buenos Aires y dispuestas, por la artista, entre las piedras a la vera del Río de la Plata. La intervención se cierra en ese punto que no es un punto de llegada, sino un pasaje más en la transformación y mutación de la obra cuando entra en contacto con lo que la degrada, la desarma, la corrompa y la desintegre. 
Potencias y alianzas de supervivencia entre mujeres.

Artículos

Liliana Maresca, un recorrido por su obra

En 1994, el artista Alejandro Kuropatwa le toma unas fotos en las que se la ve danzan$\mathrm{do}^{14}$. La artista baila mostrando un cuerpo que logra otra vez salirse, desbaratar, dejar totalmente por fuera las figurativizaciones hegemónicas que signan al cuerpo en clave agónica. En los retratos que vemos, el cuerpo está en movimiento, gira y los brazos se despliegan rítmicos hacia arriba o hacia los costados. Se trata de uno de los últimos registros de la artista poco tiempo antes de su muerte. $Y$ no hay marcas visibles de la enfermedad. Por el contrario, hay como en muchas otras de sus intervenciones, un cuerpo disponible, abierto a la entrega y la transformación. Una disponibilidad y apertura que encontramos bajo otras coordenadas en la producción de la fotógrafa Gabriela Liffschitz cuyo trabajo, realizado a fines de la década de 1990 y comienzos del nuevo siglo, supondrá transitar la experiencia de un cáncer de mama, lejos de los registros de la culpabilidad o el castigo subrayando por el contrario la intensidad y la re-invención de sí $^{15}$. En el prólogo del libro Efectos Colaterales, Liffschitz apunta:

Mi cuerpo era y es cualquier cuerpo, al que en todo caso está visto, esto podía sucederle. Yo no lograba darle sentido a la pregunta “¿Por qué a mí?". ... La diferencia residía y reside para mí en cómo podía relacionarme con esto. La diferencia la hacía lo que yo podía hacer -pensar, sentir-. Ahí estaba la singularidad, la de cualquiera. La distinción no pasaba por estar exento de la enfermedad -nunca se lo está- sino por la capacidad de uno de transformar la circunstancia en un recurso" (2004'16).

El cuerpo que vemos en las fotografías de Liffschitz, sus autorretratos, es el cuerpo intervenido por la cirugía, en el que se pone en evidencia la falta de uno de los senos. Pero la mutilación sufrida lejos de ocupar el centro de la escena convoca una serie de sentidos abiertos a la dispersión. Se nos muestra un cuerpo que atraviesa fronteras, juega con las barreras de lo femenino/lo masculino, deviene andrógino, mujer fatal, mujer niña. La reinvención del cuerpo que se produce en el campo de lo estético, desestabiliza las figurativizaciones canónicas del cuerpo enfermo para dar lugar a la emergencia de un cuerpo erotizado y deseante.

Leídas en red, en conexión, las apuestas estético políticas que llevan adelante, tanto Dillon como Liffschitz -ya sea apelando a la imagen o la escritura- pueden ser pensadas como regidas por el recorrido trazado e iniciado por Maresca. En todas, hay un cuerpo que sostenido por el deseo desafía y desbarata las construcciones hegemónicas del cuerpo enfermo. En la particularidad de cada propuesta, hay un cuerpo que responde a

${ }^{14}$ La serie de fotos puede verse en internet bajo el nombre de Alejandro Kuropatwa.

${ }^{15}$ La producción de Gabriela Liffschitz, que muere en el 2003, sobre la enfermedad es importante. Un libro titulado Un final feliz (relato sobre un análisis) (2004) y dos libros de fotografías Recursos humanos (2000) y Efectos Colaterales (2004) se destacan especialmente.

16 En la edición del texto no están las páginas numeradas.

ESCENA. Revista de las artes, 2019, Vol. 78, Núm. 2 (enero-junio), pp. 56-70 
los embates de un tiempo cuyas amenazas múltiples lo signan y lo obligan a situarse y redefinirse. Leídas en enlace y atendiendo al juego de sus re-envíos consideramos que lo que visualizan y nos ofrecen es un ejercicio de supervivencia que se replica, se contagia, se viraliza de una obra a otra, de un recorrido vital a otro. Apuestas que enfatizan, no solo la instancia del cuerpo herido en su circulación por el mundo, sino también la potencia de sus fuerzas suaves, apreciadas por Maresca: "Yo, con mi obra, estoy hablando del amor, del encuentro, de la amistad con el otro. Estoy rescatando la posibilidad de disfrutar de mi cuerpo que no se hizo para sufrir sino para gozar ${ }^{17 "}$.

\section{Referencias}

Cámara, M. (2015). De aquel amor de música ligera. Liliana Maresca y la escena de los 80 en Buenos Aires. Recuperado de http://www.academia.edu/18216261

Dillon, M. (2004). Vivir con virus. Relatos de la vida cotidiana. Buenos Aires: Norma.

Dillon, M. (2015). Aparecida. Buenos Aires: Sudamericana.

Lemus, F. (26 de enero de 2017). Liliana Maresca: fotoperformance, registros y homenajes. Revista Otra Parte. Recuperado de http://revistaotraparte.com/semanal/arte/ liliana-maresca-fotoperformance-registros-y-homenajes/

Liffschitz, G. (2003). Efectos Colaterales. Autorretratos y textos. Buenos Aires: Norma.

Meruane, L. (2012). Viajes virales. La crisis del contagio global en la escritura del sida. Chile: Fondo de Cultura Económica.

Perlongher, N. (1987). El fantasma del sida. Buenos Aires: Punto Sur.

Rosa, M. L. (2011). Fuera de discurso. El arte feminista de la segunda ola en Buenos Aires (tesis de Doctorado en Artes, Universidad Complutense de Madrid). Recuperado de http://e-spacio.uned.es/fez/eserv/tesisuned:GeoHis-MIrosa/Documento.pdf

Vaggione, A. (2012). Literatura/enfermedad. Escrituras sobre sida en América Latina. Córdoba: Editorial del Centro de Estudios Avanzados de la UNC. Disponible en http://hdl. handle.net/11086/1294

17 Entrevista a Maresca, citada por Mario Cámara (2015). 